\title{
Empowering Students for a Digital World: Global Concerns, Local School Evidence and Strategic Actions.
}

\author{
Virgilio G Medina Jr \\ Librarian \\ SEK International School Qatar \\ virgilio.medina@sek.qa \\ Ross J. Todd, PhD \\ Professor \\ School of Communication and Information \\ Rutgers, The State University of New Jersey, USA \\ rtodd@rutgers.edu
}

\begin{abstract}
The research reported here is an evidence-based development project to identify students' perceptions of how confident and competent they are in learning and working effectively in an online world, and to develop local school strategic actions. It specifically examines students'

knowledge about a range of digital competencies for online learning and living, and their confidence in using these. From a constructivist perspective, understanding their conceptions of their digital world and their confidence with engaging in it provides a window for ensuring that school libraries prepare students for this world. Available literature consistently shows that for today's young people, the digital environment is already a deeply embedded and pervasive aspect of their lives and the basis for their connections, communications, and community. Accordingly, this paper will present the findings of a school-based qualitative research study that, from the students' perspective, seeks to understand how confident they are with being safe and

productive in the online world. It will also show how these findings translate into strategic actions for the local school.
\end{abstract}

Keywords: Digital Literacy, Evidence-Based Practice, Confidence, Self-Efficacy, School Library Instruction

\section{Introduction: $21^{\text {st }}$ Century Learners}

The potential of the school library to address the challenges of $21^{\text {st }}$ century learning and to meet information and learning needs of its school community has been given considerable attention in the school librarianship literature. It centers on the belief that the school library should not only focus on fundamentals such as the physical and technological space, but as a pedagogical place where $21^{\text {st }}$ century learners develop the competencies and dispositions for effective engagement with information in all it forms to build deep knowledge and understanding, and to foster reflective thinking and problem solving (Asselin \& Doiron, 2008). In its national guidelines "Empowering Learners: guidelines for school libraries", the American Association of School Librarians asserts that "Learning in the twenty-first century has taken on new dimensions with the exponential expansion of information, ever changing tools, increased digitization of text, and heightened demands for critical and creative thinking, communication and collaborative problem solving" (p.18). This emphasizes that there are significant changes, uncertainties and demands in the roles of school libraries that library professionals are now dealing with as they serve $21^{\text {st }}$ century users whose needs are diverse and unique in different ways. 
Crick (2005) believes that engaging with various uncertainties, opportunities, capabilities, and dispositions to foster deep learning is a key skill for all learners. He also adds that "development of the capacity to learn and to go on learning is key quality for living in the $21^{\text {st }}$ century" (p.364). According to Sheppard (2000), the technological, cultural and social changes gives emphasis to the importance of civic rights of $21^{\text {st }}$ century learners by having boundless access learning opportunities - learning without borders - where learners together have seamless access to information and have the capacity to use it to co-create solution to global challenges. Lombardi (2007) positions $21^{\text {st }}$ century learning as "authentic learning that focuses on real-world, complex problems and their solutions, using role-playing exercises, problembased activities, case studies, and participation in virtual communities of practice." (p. 2) He argues that students who are exposed to authentic learning acquire "portable skills" that are essential to become an effective 21st century learner. These include: the judgment to distinguish reliable from unreliable information, the patience to follow longer arguments, the synthetic ability to recognize relevant patterns in unfamiliar contexts, and the flexibility to work across disciplinary and cultural boundaries to generate innovative solutions (p.3). Lombardi (2007) also posits that $21^{\text {st }}$ century learning should enable learners to cope up with the various complexities and problems of the real world, and particularly the challenges presented by the digital revolution. She states that addressing these challenges ensures "the better prepared they will be to deal with ambiguity" and put into practice the kind of "higher order analysis and complex communication' required of them as professionals" (Lombardi, 2007). Writing much earlier, Itin (1999) argued that a key towards the attainment of $21^{\text {st }}$ century learning goals included: pedagogical actions that create rich learning experiences; reflection on the actions and experiences; abstractions drawn from the reflection; and application of the abstractions to underpin new experiences or actions. As we consider the rapid developments of the digital landscape, it begs the question as to how confident and well prepared learners are to engage with this digital world, and how the school library is nurturing and supporting this engagement. While the concerns and challenges are global, it is the local school, the local classroom and the local school library where these learning goals are enacted.

\section{Students Engagement in the Digital World}

It is clear that student engagement plays an essential role in achieving effective and successful learning, and enables students to interact with subject matter in more meaningful ways (Herrington, Oliver, Reeves (2003). Beggs (2013), as one of many scholars, argues that the increasingly commonplace availability of, and access to digital resources challenges us to rethink the nature of classroom instruction and to engage in opportunities to understand the thinking and practices of learners so as to more effectively tailor learning experiences that support learning needs and foster thinking and growth of knowledge, and to attain learning goals and nurture the interests, capabilities and experiences of learners to adequately prepare them for their increasingly digital world. Edwards (2013) has enumerated six key drivers of student engagement in the digital world which are seen as contemporary keys to student achievement:

- Relevant learning - students who are exposed in utilizing digital resources, the more they are interested in their schoolwork activities.

- Personalized learning - real-date enables teachers to establish personalized intervention that enables students to work in a flexible collaborative groups

- Collaborative learning - digital environments promote collaboration among students and bring various talents to work together 
- Connected learning - digital resources allow student to build continuous connection to people, places, and information that stimulates learning and enhances knowledge.

- Information literacy - students are encouraged to evaluate every information they find online and validate its reliability in support to academic needs.

- Dialogical and dialectical learning - when students' perspective grow through to the continuous exposure to various resources, they become more capable to formulate substantial opinions that prepare them to a real world.

Building on this foundation, VanderArk and Schneider (2012) emphasize the central importance of personalized skill building in order to promote unique learning approaches and styles and to foster deeper learning. In addition to this, Dede (2009) acknowledges that immersive interfaces can empower educational experiences 'that build on students' digital fluency to promote engagement, learning and transfer classroom to real-world settings" (p. 66). In similar vein, Keyte-Hartland (2014) encouraging educators to create a pedagogy that is relevant and current that can synchronize to the needs of present generation, and builds on their current experiences and capabilities. Grauer (2016) asserts that technological competency is a huge part of creating meaningful pedagogical design in a digital world, and further questions the preparation of teachers and school leaders to be digitally competent in order to prepare their students for the demands of digital age.

\section{Students' safety and productivity in the digital world}

Educational authorities around the world are deeply concerned about students' engagement in the digital world. They have responded by developing standards and instructional frameworks to enable the development of digital capabilities. These typically focus on research and information competencies, creating and sharing knowledge ethically, and socializing and communicating appropriately. At the same time, local schools are concerned about immediate issues: the nature of instantaneous and permanent communications, ethical use of information and plagiarism, online identity, identity theft, cyber-bullying, digital footprints, privacy, and safety. The recently published IFLA School Library Guidelines, 2nd Ed, 2015 gives explicit attention to the role of the school library in developing a range of digital competencies that embrace these concerns. Burt (2010) raises widespread concerns about the growth of internet and how it impacts students' live by highlighting the level of safety and privacy that need to be recognized by educators as barrier to the students' learning development. Attention to standards and codes of conduct when it comes of being online or connected to online world is increasing exponentially (Shariff, 2005).

Ensuring students' internet safety seems to be on the priority list that various stakeholders and educators are now focusing on (Duerager \& Livingstone, 2012). They also discuss that being online is taken for granted, and that, for example European children spend approximately 88 minutes online, almost one hour for 9-10 years old while two hours for 15-16 years old. Consequently, Kidshealth organization has been established to educate people on the possible risks on the internet; they believe that parents or adults are obliged to be aware on what children witness in being online (2016). To minimize and weaken the possible negative impacts of internet use, parent and guardians need to gain knowledge about safety and risks associated with both online and offline worlds (National Center for Missing and Exploited Children \{2016]).

Livingstone, Haddon, Gorzig, \& Olafsson (2010) are known with their advocacies and commitments in educating people on risks and safety for children on the internet. They believe that 'Digital Literacy' plays a significant role in deepening and strengthening teffective online 
inquiry, and making students aware of online risks. They investigate how this skill can empower students to identify online risks. They indicate that providing personal information is the most common problem that majority of students tend to face. Thus, it can be stated that these major skills and problems mentioned could be a starting point to further strengthen and develop an action plan equipping students to be competent in evaluating and using information from the web.

\section{Confidence and Competence in the Digital World}

A growing body of scholarly literature is addressing the central concepts of confidence and competence of learners as they engage in the digital landscape. Bandura (1994) introduces the term "self-efficacy", defined as "people's beliefs about their capabilities to produce designated levels of performance that exercise influence over events that affect their lives". In short, relying on personal belief and capacity to overcome and manage set of actions. He also enumerates four references of self -efficacy:

- Mastery Experiences - explains that success increases self-efficacy; failure weakens it.

- Vicarious Experiences - pertains to observations made from other social situations.

- Verbal persuasion - focuses on encouragement and discouragement gathered from other people.

- Physiological factors - refers to own personal responses and emotional reactions to situations.

Scott (1966) argues that self-efficacy does not only focus on one's capacity but on what individual thinks needs to be accomplished. He also believes that self-efficacy heightens students" motivation and performances in a given situation. A good example is when students exert effort to succeed in the school; it is believed that these students have better cognitive tasks (Skinner, Wellborn, \& Connell, 1990). Thus, self-efficacy also improves when success seems to be attainable and when confidence is high.

Self-efficacy not only applies to students, but to teachers as well. Henson (2001) cites early research that suggests "powerful effects" from the simple idea that a teacher's beliefs in his or her ability to positively impact student learning are critical in actual success for failure in a teacher's behavior". Protheroe (2008) explains that those teachers who view their roles as a critical part of students' success meet the high standard, which is the concept of teacher efficacy.

The literature that we have explored speaks about the students' "confidence" as well as their self-efficacy. From a psychological perspective, "an $n$ individual's self-confidence is derived from affective memories of past experiences of engaging in an activity or upon judgments of one's capabilities to organize and execute courses of action to attain specific goals" (Vogt, n.d). In addition, the relationship of self esteem, self-confidence, and self-concept explains individual's capacity and worth in comparison to other skills (Klassen, 2010). One of the key findings that emerges is that, according to Stankov (2011), confidence is much stronger predictor of students' achievements than any other non-cognitive measure. In other words, there is a relationship between perceptions of confidence and competence. According to Watson (2001), a key dynamic is engaging students in carefully planned and targeted instruction to develop critical thinking and problem solving, which also plays a strong role in influencing levels of competence, and resulting users' confidence. 


\section{Digital competencies for the digital world}

To be able to grasp the rapid changes of the digital environment, various skills related to competence and technical skills, ranging from digital to isocial and communication skills, need to be acquired. As explained by Deursen, Van Dijk, \& Peter (2011), the technological changes in the society have foiled the concept of internet skills, which normally correlates to the level of educational attainment.

Deursen \& Van Dijk (2009) introduce four types of digital skills in order to help individuals to operate effectively in a digital world:

- Operational skills - operating, encoding and exploring internet browser

- Format Internet skills - navigating and using links/formats

- Information Internet skills - locating, searching, defining, selecting and evaluating resources

- Strategic Internet skills - maximizing the advantages of the internet

Moreover, using technology in an acceptable manner and behavior is also considered. Ribble is well known educator who proposed the idea of Digital Citizenship that defines as "the norms of appropriate, responsible technology use" (2016). This concept aims to guide and help educators, teachers, parents, and students to utilize technology in most effective and acceptable way. Along with this, their approach consists of nine themes, discussing essential issues on the use of technology:

1. Digital Etiquette: electronic standards of conduct or procedure.

2. Digital Communication: electronic exchange of information.

3. Digital Literacy: process of teaching and learning about technology and the use of technology.

4. Digital Access: full electronic participation in society.

5. Digital Commerce: electronic buying and selling of goods.

6. Digital Law: electronic responsibility for actions and deeds.

7. Digital Rights and Responsibilities: those freedoms extended to everyone in a digital world. 8. Digital Health and Wellness: physical and psychological wellbeing in a digital technology world.

9. Digital Security (self protection): electronic precautions to guarantee safety.

It is often believed that in order for these competencies to be successful, a well-established digital program must be implemented in a school library program and action plan (IFLA School Library Guidelines, 2015)

All of this review and analysis begs the question: how well do we actually know where our students are at with their engagement and use of the digital world? How well do we understand their levels of competence and confidence in order to provide the appropriate, meaningful and deep learning experiences? The local school evidence-based initiative reported here provides a starting point for one school to move forward with its digital learning agenda. The focus of this initiative is gathering insights into students' confidence and competence as a starting point for developing a school library action plan that fosters appropriate, meaningful and deep learning experiences.

The evidence-based practice approach used here draws on the work of Todd $(2009,2015)$. Evidence-based school librarianship is an approach to professional practice that systematically 
engages research-derived evidence, school librarian-observed evidence and user-reported evidence in iterative processes of decision making, development and continuous improvement to achieve the school's mission and goals, which fundamentally center on student achievement, quality learning and quality teaching. At the heart of evidence-based practice is supporting students' information-to-knowledge experience enabled though school library initiatives. Its dayby-day practice meshes professional insights, reflective experience and understanding of user needs with the judicious use of systematically collected local evidence to make judgments and decisions about how to deliver the instructional and service roles of the school library to meet the goals of the school.

\section{Sample, Methods and Data Collection}

As stated above, this study sought to gather some data in a specific school on how confident and competent students perceived themselves to be in knowing about how to work effectively and safely in online worlds. Consistent with the review of the literature presented above, its goal was not to provide generalizable findings; rather to provide input to guide the strategic planning for the library's instructional directions and service provision. The sample for this study was drawn from students in Grades 5-10 at a private school in Qatar. This school is a relatively new school in the country, and prides itself in terms of pedagogical and technological leadership, active global citizenship, as well as multicultural and international education. 148 students completed a survey questionnaire to ascertain their level of confidence. These students were participating in regularly scheduled library and literacy classes, and the survey was completed as part of that schedule. Data were collected through a self-reported responses to 28 items using a modified and extended checklist, as well as open-ended questions, developed by the Open University UK titled "Being digital: Digital literacy skills checklist" available at: http://www.open.ac.uk/libraryservices/beingdigital/accessible/accessible-pdf-35-selfassessment-checklist.pdf. The checklist consisted of 28 items that measured level of confidence - from very confident to not confident at all. These items focused on four key dynamics: Understanding digital practices; Finding information; Using information, and Creating information. Included in the checklist instrument were a set of open ended questions which further sought to gain insights into their perceptions of competence. We did this by asking the students to identify the factors they found difficult and easy to do in relation to learning in the digital information world, and how they saw that the school library might help them.

Table 1 shows the grade distribution of students:

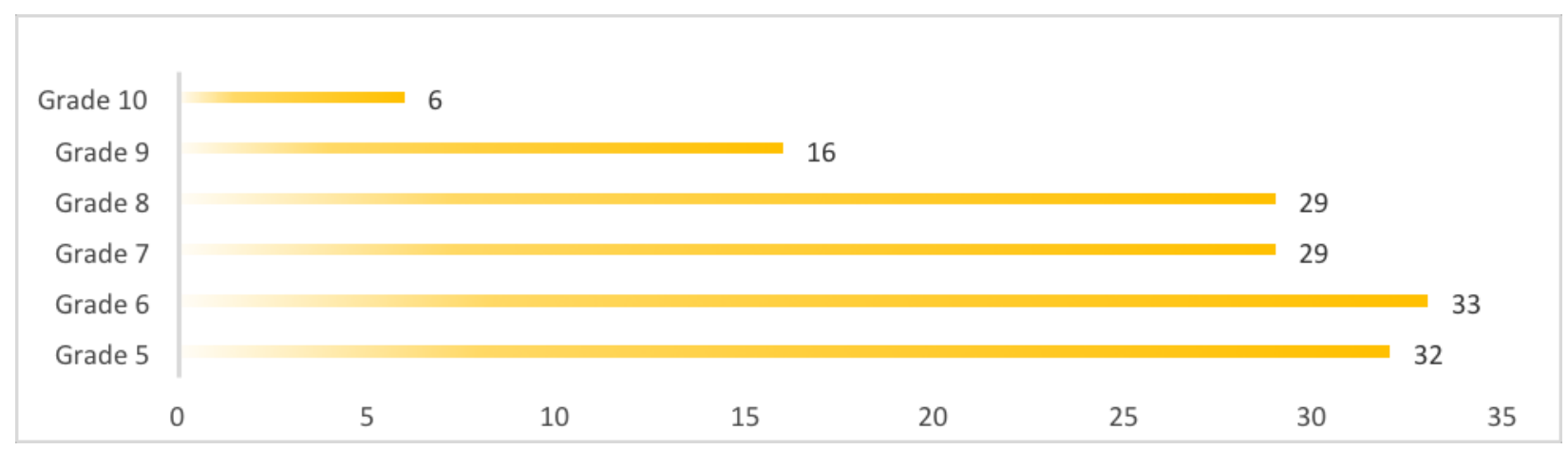

Table 1: Number of students per grade level

Of the 148 responses from the students, $41 \%$ are girls and $59 \%$ are boys. 


\section{Levels of Confidence}

Table 2 shows the checklist items and the percentage distribution of levels of confidence for each item.

\begin{tabular}{|c|c|c|c|c|c|}
\hline Skills & $\begin{array}{c}\text { Very } \\
\text { confident }\end{array}$ & $\begin{array}{l}\text { Quite } \\
\text { confident }\end{array}$ & Somewhat & $\begin{array}{l}\text { Slightly } \\
\text { confident }\end{array}$ & $\begin{array}{l}\text { Not } \\
\text { confident } \\
\text { at all }\end{array}$ \\
\hline $\begin{array}{l}\text { 1. I know who are all the people I } \\
\text { chat with online }\end{array}$ & 64.4 & 17.9 & 6.4 & 7.9 & 1.4 \\
\hline $\begin{array}{l}\text { 2. I know what happens to } \\
\text { information that I share online }\end{array}$ & 43.6 & 44.3 & 7.1 & 2.9 & 2.1 \\
\hline $\begin{array}{l}\text { 3. I know how to choose the right } \\
\text { tool to find, use, or create } \\
\text { information }\end{array}$ & 37.9 & 44.3 & 14.3 & 2.9 & 0.7 \\
\hline $\begin{array}{l}\text { 4. I know how to share information } \\
\text { about myself online }\end{array}$ & 61.4 & 26.4 & 5.7 & 3.6 & 2.9 \\
\hline $\begin{array}{l}\text { 5. I know how to find a person } \\
\text { online to answer my questions }\end{array}$ & 32.9 & 37.1 & 17.1 & 7.1 & 5.7 \\
\hline $\begin{array}{l}\text { 6. I know how to search for good } \\
\text { information online }\end{array}$ & 51.4 & 40.7 & 5.7 & 1.4 & 0.8 \\
\hline $\begin{array}{l}\text { 7. I know how to tell if the online } \\
\text { information I find is good } \\
\text { information }\end{array}$ & 42.9 & 45.7 & 8.6 & 2.1 & 0.7 \\
\hline $\begin{array}{l}\text { 8. I know how to cite the web } \\
\text { information that I find for a } \\
\text { research project }\end{array}$ & 38.6 & 45 & 11.4 & 3.6 & 1.4 \\
\hline $\begin{array}{l}\text { 9. I know what to do when I see } \\
\text { the word "copyright" on a web site }\end{array}$ & 37.1 & 25.7 & 24.3 & 6.4 & 6.4 \\
\hline $\begin{array}{l}\text { 10. I know how to use a computer } \\
\text { to find information in the }{ }^{* * *} \text { library }\end{array}$ & 27.9 & 25 & 25 & 10.7 & 11.4 \\
\hline $\begin{array}{l}\text { 11. When I search for information } \\
\text { online, I know how to use the } \\
\text { advanced search option }\end{array}$ & 17.9 & 16.4 & 25.7 & 9.3 & 30.7 \\
\hline $\begin{array}{l}\text { 12. I know how to search online } \\
\text { using keywords }\end{array}$ & 45.7 & 33.6 & 13.6 & 5 & 2.1 \\
\hline $\begin{array}{l}\text { 13. I know when to change my } \\
\text { search strategy or stop searching }\end{array}$ & 35.7 & 42.1 & 14.3 & 5.7 & 2.1 \\
\hline $\begin{array}{l}\text { 14. I know how to scan and skim a } \\
\text { web page to get information }\end{array}$ & 26.4 & 25.7 & 27.1 & 11.4 & 9.3 \\
\hline
\end{tabular}




\begin{tabular}{|l|l|l|l|l|l|}
$\begin{array}{l}\text { 15. I know how to find out if } \\
\text { information on the web is up-to- } \\
\text { date }\end{array}$ & 35 & 32.9 & 20 & 5.7 & 6.4 \\
\hline $\begin{array}{l}\text { 16. I know how to work out if the } \\
\text { online information I find is accurate }\end{array}$ & 31.4 & 44.3 & 17.9 & 5 & 1.4 \\
\hline $\begin{array}{l}\text { 17. I know how to add comments } \\
\text { to blogs, forums or web pages }\end{array}$ & 62.9 & 22.9 & 3.6 & 4.3 & 6.4 \\
\hline $\begin{array}{l}\text { 18. I know how to write online } \\
\text { blogs/webpages }\end{array}$ & 41.4 & 22.9 & 17.1 & 7.9 & 10.7 \\
\hline $\begin{array}{l}\text { 19. Writing in different media for } \\
\text { people to read on screen }\end{array}$ & 29.3 & 27.1 & 27.9 & 10.7 & 5 \\
\hline $\begin{array}{l}\text { 20. I know how to talk with others } \\
\text { safely online }\end{array}$ & 68.6 & 20.7 & 7.1 & 2.1 & 1.4 \\
\hline $\begin{array}{l}21 . \text { I know the rules for } \\
\text { downloading information from the } \\
\text { web }\end{array}$ & 50 & 28.6 & 12.9 & 5.7 & 2.9 \\
\hline $\begin{array}{l}22 . \text { I know how to use podcasts or } \\
\text { videos in my research projects }\end{array}$ & 39.3 & 32.1 & 15.7 & 7.1 & 5.7 \\
\hline $\begin{array}{l}23 . \text { I know how to keep track of } \\
\text { relevant online information that I } \\
\text { find }\end{array}$ & 45.7 & 36.4 & 12.1 & 5.7 & 0 \\
\hline
\end{tabular}

Table 2: Percentage distribution of levels of confidence for each item

Table 3 shows the items where the students expressed highest levels of confidence (based on Very Confident and Quite Confident scores, in order from highest to lowest).

\begin{tabular}{|l|c|}
\hline Skills (Very Confident and Quite Confident) & $\%$ \\
\hline 6. I know how to search for good information online & 92.1 \\
\hline 20. I know how to talk with others safely online & 89.3 \\
\hline $\begin{array}{l}\text { 7. I know how to tell if the online information I find is good } \\
\text { information }\end{array}$ & 88.6 \\
\hline 2. I know what happens to information that I share online & 87.9 \\
\hline 4. I know how to share information about myself online & 87.8 \\
\hline $\begin{array}{l}\text { 25. I know how to book mark web information so I can use it at } \\
\text { another time }\end{array}$ & 86.4 \\
\hline 17. I know how to add comments to blogs, forums or web pages & 85.8 \\
\hline 27. I know how to identify important ideas in a web site & 84.3 \\
\hline $\begin{array}{l}\text { 8. I know how to cite the web information that I find for a research } \\
\text { project }\end{array}$ & 83.6 \\
\hline 28. I know how to organize all the ideas I find in websites & 82.9 \\
\hline
\end{tabular}




\begin{tabular}{|l|l|} 
1. I know who are all the people I chat with online & 82.3 \\
\hline $\begin{array}{l}\text { 3. I know how to choose the right tool to find, use, or create } \\
\text { information }\end{array}$ & 82.2 \\
\hline 23. I know how to keep track of relevant online information that I find & 82.1 \\
\hline 12. I know how to search online using keywords & 79.3 \\
\hline 21. I know the rules for downloading information from the web & 78.6 \\
\hline 13. I know when to change my search strategy or stop searching & 77.8 \\
\hline 16. I know how to work out if the online information I find is accurate & 75.7 \\
\hline 24. I know which files on the web I am allowed to share & 74.3 \\
\hline 22. I know how to use podcasts or videos in my research projects & 71.4 \\
\hline 5. I know how to find a person online to answer my questions & 70 \\
\hline 15. I know how to find out if information on the web is up-to-date & 67.9 \\
\hline $\begin{array}{l}\text { 26. I know how to use websites like Twitter or Facebook as a source } \\
\text { of information }\end{array}$ & 65.7 \\
\hline 18. I know how to write online blogs/webpages & 64.3 \\
\hline 9. I know what to do when I see the word "copyright" on a web site & 62.8 \\
\hline 19. Writing in different media for people to read on screen & 56.4 \\
\hline $\begin{array}{l}\text { 10. I know how to use a computer to find information in the *** } \\
\text { library }\end{array}$ & 52.9 \\
\hline 14. I know how to scan and skim a web page to get information & 52.1 \\
\hline $\begin{array}{l}\text { 11. When I search for information online, I know how to use the } \\
\text { advanced search option }\end{array}$ & 34.3 \\
\hline
\end{tabular}

Table 3: Rank order of confidence levels

Overall it suggests that the highest levels of confidence relate to technical skills of using digital tools, competencies related to accessing and selecting information sources, and perceptions of personal capacity and participation in online environments. Higher levels of confidence revolve around searching for information, finding information, evaluating sources, and keeping track of found information through bookmarking and citations. Students seem confident with participating in networked digital environments, including participating in forums, chatting with others online, and convey an understanding of what happens with their own information shared online. Lowest levels of confidence center on higher levels of technical skills, such as advanced search options; using nontraditional information sources (such as Twitter and Facebook as information sources, ) and integrating and using different media into research projects as different approaches to representing ideas. At the same time, some of the more complex cognitive skills - such as analysis and synthesis of information and the construction of one's own knowledge seem to generate lower levels of confidence. And this we believe is $t$ the heart of the instructional role of school librarians.

\section{Confidence patterns in relation to gender}


Overall, there were few differences in confidence levels between boys and girls. Both boys and girls seem to be confident with managing their digital lives, and confident about their actions and skills. There were a small set of differences between boys and girls, and these are:

- Male students' confidence level of knowing who are all the people they chat with online $(M=3.56, S D=0.83)$ is significantly higher than female students $(M=3.16, S D=1.19)$; $\mathrm{t}(93.05)=2.21, \mathrm{p}=0.030$

- Male students' confidence level of knowing what to do when they see the word "copyright" on a web site $(M=3.01, S D=1.13)$ is significantly higher than female students $(\mathrm{M}=2.49, \mathrm{SD}=1.23) ; \mathrm{t}(137)=2.58, \mathrm{p}=0.011$

- Male students' confidence level of knowing how to scan and skim a web page to get information $(M=2.77, S D=1.15)$ is significantly higher than female students $(M=2.05$, $\mathrm{SD}=1.29) ; \mathrm{t}(137)=3.44, \mathrm{p}=0.001$

- Male students' confidence level of writing in different media for people to read on screen $(M=2.80, S D=1.14)$ is significantly higher than female students $(M=2.40, S D=1.15) ; t$ $(137)=2.04, p=0.043$

- Male students' confidence level of knowing which files on the web they are allowed to share $(M=3.22, S D=1.05)$ is significantly higher than female students $(M=2.79$, $\mathrm{SD}=1.18) ; \mathrm{t}(137)=2.06, \mathrm{p}=0.026$

While historically it is acknowledged that adult males dominate the information technology sector in terms of design of software, games and the uptake of diverse tools and gadgets, the findings here suggest opportunities to enable all students to succeed through a range of interventions: peer mentoring to develop technical capacity around integration of multiple medias, direct instruction and sustained development of cognitive and reflective capabilities round the complex processes of knowledge construction.

\section{Differences in confidence levels by grades}

It appears that the students mostly selected "quite confident" and "very confident" for most of the given questions, regardless of grade level. The confidence levels on the following skills are significantly different among different grades.

- The confidence level in relation to knowing who are the people they chat with online is significantly different in some grades. Pairwise comparisons with adjusted $p$-values showed that there were no significant differences between confidence level when grade 6 is compared to grade $5(p=.095, z=2.73)$, grade $7(p=.098, z=1.85)$, and grade 10 $(p=1.000, z=1.11)$. However, there were significant differences between confidence level when grade 6 is compared to grade $8(p=.041, z=2.99)$, and grade $9(p=.022, z$ $=3.19$ ). Grade 6 has significant lower confidence level, compared to grade 8 and grade 9.

- The confidence level in relation to knowing how to find a person online to answer my questions shows some grade differences. Grade 5 and grade 7 were significant different $(p=.004, z=3.66)$. Grade 7's confidence level was significantly higher than Grade 5.

- The confidence level in relation to knowing how to use the advanced search option shows some grade differences. Grade 6 and grade 8 were significant different $(p=.002$, $z=3.83$ ). Grade 6's confidence level was significantly lower than Grade 8 and Grade 10.

- The confidence level in relation to knowing how to use websites like Twitter or Facebook as a source of information shows some grade differences. Grade 5 and grade 8 were 
significant different $(p=.038, z=3.02)$. Grade 5 and Grade 7's confidence levels were significantly lower than Grade 8.

While the survey did not ascertain the reasons or explanations for these grade differences, It appears that 7th grade and 8th grade are a key period of time when young people become confident in consulting interpersonal resources (from questions on Know who are the people I chat with online and Know how to find a person online to answer my questions). Additionally, when young people enter 8th grade, it appears that they have grown confidence significantly in terms of their information searching and using social networks skills. This finding is in line with how teenagers and preteens are commonly characterized. For example, Meyer, Fisher, \& Marcoux (2009) note that teenagers are characterized as "a population with significantly greater autonomy and mobility than preteens and thus greater capacity for creating and using social networks that might facilitate interpersonal information behaviors" (p.304). They further draw upon Vygotsky's developmental theory, indicating "adolescence as a critical period in the development of children's mental and social functioning. Qualitative changes in social development and meaning making define this period. Preteens begin to think conceptually and to take steps toward the formation of higher mental processes" (p.306).

\section{Perceptions of competence}

The survey asked students to respond to three open ended questions. These were designed to gather insights into students' perceptions of their competence with accessing and using the vast amount of information that is available digitally. The questions were: 1 . Name some things that you find easy to do online?; 2. What some of the difficulties you encounter when you are online? and 3. What do you think that the (school) library can do for you to help you to become a good online learner?

\section{Name some things that you find easy to do online?}

This question generated 123 responses. While a diverse set of things were identified by individual students as easy to do online, ranging from evaluating information for accuracy, reliability, and relevance, accurate citation, and researching for particular class projects, the analysis of the open ended responses identified four predominant categories: information searching and finding, chat, and a range of technical capabilities around saving and transferring information. There was limited resistance to the notion of "easy", and this counter-voice stands out: "When it comes to online it is never easy, but it always depends. Sometimes i search for information and find my exact answers, sometimes I search for information and it takes me hours to find my answers or I may not even find them at all, it depends. I think it is easy to communicate with people online". At the same time, a telling statement was: "Everything but finding good websites". Each of the categories will be briefly elaborated.

1. Information searching and finding. Students consistently reported that they competent searchers, using Google in particular as their primary search engine to identify potentially useful sources of information through links provided in Google outputs as well as topical facts, and deploying key words to find needed information. Some comments illustrative of this category are: "I can easily find information about the past (or something like that) by searching on Google"; "I know how to book mark a website"; "I know how to use keywords and I know when to try different words in my search"; "I think that looking for information is not very challenging for me and I also know how to know if the website is reliable or not"; and "It's easy to research basic information and general facts on Google." 
2. Chat, chat, and more chat. Students found using digital tools to enable online conversations as the easiest thing to do. Their digital lives seem to revolve around online chatting and messaging with friends, and using these connections to keep up on group activities, socializing, discovering and sharing new things, doing homework together, and participating in gaming activities. Some comments illustrative of this category are: "Chat with your friends, know what are your friends doing, watch videos, play games together, have a good time"; "Send messages on online"; "Interacting with people using social media"; "Using social media, texting friends via social media, watching videos, discovering new songs, taking images off of the internet etc"; and "Go on Facebook and do my homework; I can talk to known people online so they can tell me about my researched theme". There was some awareness by two students some of the ethics involved, for example: "Keep safe all my personal information as well as posting proper things. Look information in different resources and not just copy one".

3. Save and transfer capabilities: Students indicated considerable ease with save and transfer functions of the online environment. Some comments, albeit concerning comments, illustrative of this category are: "One of the easiest things I can do is save all the websites that I see relevant and important for my assignment. I also can know if the websites I find is reliable or not; go on Youtube, Instagram and these type of webpages"; "When I like the website I can easily bookmark it"; "The easiest thing that I find to do online is Bookmark and copy/paste"; "I know how to C and P"; "Copy-paste, bookmark, type, cite, comment in blogs, collecting information etc".

\section{What some of the difficulties you encounter when you are online?}

This question generated 106 responses, and 15 responses indicated no difficulties at all, at least on the surface or perhaps naively: "I really don't find anything hard. If I did I could just Google it or search it on Youtube". The analysis of the responses indicates three predominant categories of difficulties that revolve around source and information evaluation, dealing with digital disruptions, and information construction.

1. Information evaluation. This centered on recognizing the on-screen indicators that signify quality of a website, and sorting through large quantities of retrieved information to identify useful content. Some illustrative comments include: "Sometimes is difficult to find the date when the web page was written, its author"; "It's pretty difficult to find content that is relevant to what you are searching. You can often find useless content while you are searching for something. Another challenging thing is to find a useful website, which is also safe. For example, a website that doesn't send you cookies or scans"; "Coming to an inappropriate website with wrong facts"; "Being confident with the information that I gather, knowing that they are accurate for example. I find research one of the hardest tasks because of the various number of information and how they are meant to be based on the same topic yet diverse".

2. Managing digital disruptions and transfers: These difficulties centered on technical actions in the process of searching and understanding why these are happening. These include popups, advertisements, scams, and viruses. Some illustrative comments include: "I think the most difficulties are the ads that pop up when you open a website"; "One thing I find difficult when I am online is when it comes to downloading. Over the last few months we have downloaded many things to help us with our learning experiences. However, I am not entirely sure which programs are safe to use, don't take up much space on the computer's hard-drive or even work properly. I try to use safe sites such as Microsoft but when that's not an option, I often get lost"; "Spam advertisements, fake download files, Trojan viruses"; "The difficulties I encounter when I 
am online are fake download files (viruses). I accidentally download something that I never wanted and know it is stuck on my laptop"; "You can get scammed on the internet. It happened to me once where I had to pay for something that never came"; and "When they are websites with so many advertisements then I cant see anything, and websites which are not checked so they contain viruses".

3. Information organization, analysis and synthesis: Sixteen students, particularly in the upper grades, acknowledged that finding information is just the start of a longer information-toknowledge journey, and identified the challenges inherent in sorting through all the information, identifying relevant ideas, and then combining these into a worthwhile representation. Some illustrative comment include: "It is difficult to put all the information in a good paragraph that make sense without plagiarism"; "It is hard to find some good websites and stay on it and take as much information as written that makes sense for the research project"; and "I have trouble putting it all together as I end up with piles of folders with stuff and do not know what to do with them".

\section{What do you think that the (school) library can do for you to help you to become a good online learner?}

For this question, 112 responses were recorded. Responses show a parallel between online difficulties and help needed. There were five distinct categories of help identified in these responses, as well as some important insights into how these might be provided. These center on intellectual property, information organization and analysis, internet safety, digital reading, and research competencies. Two students connected these competencies to life beyond school, for example: "According to the modern world these skills are vital to learn because it is what our society deals with everyday, it is almost the same as having the skill of literacy", and "I now how to work with technology in my future job".

1. Intellectual property: In acknowledging at times that copy and paste were easy to do, students were aware of practices and requirements around plagiarism and citation, and the short term consequences of inappropriate use of information., and sought guidance and help. This was particularly evident in Grades $8-10$, and indicated in the following illustrative comments: "Make sure we aren't illegally copying"; "More lessons on how to cite properly and use APA format. We use this format in nearly every subject that we need to cite in and I think it is important because this is a large part of the IB" ; and "In order to become a good on-line leaner I need to know how to site my sources". One student stated: "we had some presentations about academic honesty and how to cite our sources so these presentations helped ,so I think if we get more of these presentations that would be very helpful".

2. Information organization, analysis and synthesis: From the students' perspective, the cognitive tasks of analysis, synthesis and organization of information are perceived to be difficult, as documented above, and they want help with these tasks. Some comments illustrative of this category are: "knowing how to pick the key points"; "Use the information correctly in more detail to write my project"; "Learning and organizing ideas that I find on the websites and how important it is to put these together". Students are aware that finding appropriate resources is not enough. They know that they have to do something with the found information, and this is where the difficulties begin.

3. Digital reading: There is a growing body of research beginning to emerge around online reading versus paper-based reading, including the critical evaluation of information form diverse online sources. In this survey, 25 students seemed to have awareness of the complexities of 
online reading and suggested that help be provided to help them improve their online reading abilities. Some comments illustrative of this category are: "I need to know how to become a good online reader"; "I want some tips for becoming a good online reader"; "With all the links, I get lost and want to keep track of my reading and that is hard to do".

4. Research process: At all grade levels, there were ample responses for helping students become better researchers. They wanted to know the integrated stages of doing research, feedback on their tasks involved in doing research, and avoiding research pitfalls, including such things as accurate and appropriate information. While some students expected this to be accomplished through checklists of tips and strategies which could be practiced, some other students saw it as longer term and deeper process. Some illustrative comments include: "Guide me through my research and also give me some tips for my future experiences"; "Teach us about different things related to research then give us a research task that we can complete individually or in groups to make sure we understand what to do"; "Tell me the right thing to do in each research step and also by telling me tricks. After that I will practice on what I learn"; "You could teach us some tips and strategies concerning the research process"; "You can teach me some tricks to became a good online learner and researcher and don't make mistakes in the internet or any social media"; and "Help us develop research skills and help us with things like, citations and how to identify trustful websites from none-trustful ones".

5. Internet safety: While the Likert scores on the level of confidence on most items were high, confidence does not necessarily translate into competence. Twelve students expressed the need for help in developing their own expertise with being safe and productive in online environments. Safety was often equated with quality, and in their searches for quality information, they wanted to be safe, and not to encounter websites that unknowingly compromised their safety. "Some illustrative comments include: "Dedicating a library lesson on how to stay safe and find accurate information online at the same time"; "Guiding you by showing what websites are safe and contain good and appropriate information, and what these look like"; and "Session on how to be safe in the social media and how to avoid online conversation with people that we don't know". As one student aptly put it: "About having a safe life while you are navigating through the internet and web sides".

In all of the dimensions of help, one aspect is very predominant, and that is the role of the school library as an instructional center. In terms of how these helps might be enacted, students clearly identified the role of and need for instruction. This is conveyed in quotes above, and it recurred predominantly. The library in the school was seen as a pedagogical center and not just a resource center, where these competencies are, and can be taught, and where students recognize that they can be taught. Some illustrative comments include: "Teach us to identify different types of information"; "Teach me how to used the school library website"; "Find out the majority of students who need help on one specific thing and then in one library session teach the students what they need to learn"; "Teach us how to search with key words" and "Give us tutorials on the areas of technology that we are not familiar with in this survey".

\section{Moving forward}

One of the goals of this school-based survey was to provide the school librarian with some systematically gathered student-centered data to develop a set of guidelines that could translate into local evidence-based strategic actions to engage a school community in a holistic approach to digital literacy development. The use of the Open University UK "Being digital: Digital literacy skills checklist" provided an easily administered and managed approach to gathering this evidence, and can easily be replicated across grade levels as the school library systematically 
engages in evidence-based practice. It can be applied across a range of grade levels, or it can be used in relation to one class to guide the development of actions, particularly instructional interventions. Given that the students in this study expressed the need for help in terms of instruction, this becomes a powerful tool in working with the students to develop the approaches to instruction. It also ensures that the school library is a dynamic window to the real and online world of students for reading, writing and communication.

The following diagram shows the conceptual and instructional framework for the development of digital capacity in the school in question. It brings together the most predominant difficulties and helps identified in the survey, and at the same time, acknowledges and builds on high levels of confidence. Confidence does not equal competence; rather, it is an important foundation for the development of competence. The framework also shifts the instructional approach from searching and finding information, although it is noted that some students particularly in lower grades need help in this regard, to a more research-centric and information engagement framework.

Research Processes and Effective

Reading in Digital Environments:

Stages, processes, strategies, and

immersive experiences wtih

feedback loops

\section{Instruction for
Digital Competency \\ Instruction for
Digital Competency}

\section{Digital Safety: Personal safety; technical safety; managing technical disruptions}

Intellectual Property: Citation,

authority, copyright, ethical use of information
Knowledge Construction:

Information evaluation,

organization, analysis and synthesis

From Digital Confidence to Digital Competence: An Evidence-Based Action Plan

At the IASL conference in Tokyo, we will provide an update on the further elaboration of this action plan.

\section{References:}


American Library Association. (2009). Empowering Learners: Guidelines for School Library Programs.

Asselin, M., \& Doiron, R. (2008). Towards a transformative pedagogy for school libraries 2.0. School Libraries Worldwide, 14(2), 1-18.

Bandura, A. (1994). Self-efficacy. John Wiley \& Sons, Inc..

Basic Internet Safety. (2016). Netsmartz.org. Retrieved 6 June 2016, from http://www.netsmartz.org/InternetSafety

Beggs, P., Shields, C., Telfer, S., \& Bernard, J. L. (2013). Extending the Landscape and Enlarging the Vision: Pedagogy, Technology, and Innovative Practices in a Digital World.

Burt, R. (2016). We should talk - what are you doing to ensure student safety online?.Edublog. Retrieved from http://edublogs.org/2010/11/30/we-should-talk-what-are-you-doing-to-ensurestudent-safety-online/

Crick, R. D., \& Wilson, K. (2005). Being a learner: A virtue for the 21st century. British Journal of Educational Studies, 53(3), 359-374.

Dede, C. (2009). Immersive interfaces for engagement and learning. science,323(5910), 66-69.

Duerager, A., \& Livingstone, S. (2012). How can parents support children's internet safety?.

Edwards, M. (2016). The 6 Key Drivers of Student Engagement -- THE Journal. THE Journal. Retrieved 5 June 2016, from https://thejournal.com/articles/2013/04/16/the-6-key-drivers-ofstudent-engagement.aspx

Grauer, K. (2016). Pedagogy in a digital world - International Innovation. International Innovation. Retrieved 2 June 2016, from http://www.internationalinnovation.com/pedagogy-in-a-digitalworld/

Hasebrink, U., Livingstone, S., Haddon, L., \& Ólafsson, K. (2009). Comparing children's online opportunities and risks across Europe: cross-national comparisons for EU Kids Online. LSE, London: EU Kids Online. ht tp.eprints. Ise. ac. uk/24368.

Herrington, J., Oliver, R., \& Reeves, T. (2003). 'Cognitive realism in online authentic learning environments.

Henson, R. K. (2001). Teacher self-efficacy: Substantive implications and measurement dilemmas.

IFLA School Libraries Section Standing Committee. (2015). IFLA School Library Guidelines (2nd ed.). Retrieved from:

Internet Safety. (2016). Kidshealth.org. Retrieved 1 June 2016, from http://kidshealth.org/en/parents/net-safety.html

Itin, C. M. (1999). Reasserting the philosophy of experiential education as a vehicle for change in the 21st century. The Journal of Experiential Education,22(2), 91. 
Keyte-Hartland, D. (2014). Pedagogy of the Digital World. Debikeytehartland.me. Retrieved 4 June 2016, from https://debikeytehartland.me/2014/12/05/pedagogy-of-the-digital-world/

Klassen, R. M. (2010). Confidence to manage learning: The self-efficacy for self-regulated learning of early adolescents with learning disabilities. Learning Disability Quarterly, 33(1), 1930.

Livingstone, S., Haddon, L., Görzig, A., \& Ólafsson, K. (2010). Risks and safety for children on the internet: the UK report: full findings from the EU Kids Online survey of UK 9-16 year olds and their parents.

Lombardi, M. M. (2007). Authentic learning for the 21st century: An overview. Educause learning initiative, 1(2007), 1-12.

Scott, J. E. (1996). Self-efficacy: A key to literacy learning. Reading Horizons,36, 195-213.

Meyers, E. M., Fisher, K. E., \& Marcoux, E. (2009). Making Sense of an Information World: The Everyday-Life Information Behavior of Preteens. The Library, 79(3).

Protheroe, N. (2008). Teacher Efficacy: What Is It and Does It Matter?.Principal, 87(5), 42-45.

Ribble, M. (2011). Digital Citizenship in Schools (2nd ed., pp. 15-45). Retrieved from https://www.iste.org/docs/excerpts/DIGCl2-excerpt.pdf

Shariff, S. (2005). Cyber-dilemmas in the new millennium: School obligations to provide student safety in a virtual school environment. McGill Journal of Education, 40(3), 467.

Sheppard, B. (2016). The 21st Century Learner. (pp. 1-17). Washington, DC: Eric. Retrieved from http://files.eric.ed.gov/fulltext/ED448788.pdf

Skinner, E. A., Wellborn, J. G., \& Connell, J. P. (1990). What it takes to do well in school and whether I've got it: A process model of perceived control and children's engagement and achievement in school. Journal of educational psychology, 82(1), 22.

Stankov, L. (2011). Strong Links between Self-Confidence and Math Performance | SingTeach | Education Research for Teachers. Singteach.nie.edu.sg. Retrieved 12 April 2016, from http://singteach.nie.edu.sg/issue29-mathed/

The Open University. (2012). Being digital: Digital literacy skills checklist (1st ed.). Retrieved from http://www.open.ac.uk/libraryservices/beingdigital/accessible/accessible-pdf-35-selfassessment-checklist.pdf

Todd, R. J. (2009). School librarianship and evidence based practice: Progress, perspectives, and challenges. Evidence Based Library and Information Practice, 4(2), 78-96.

Todd, R. J. (2015). Evidence-based practice and school libraries: Interconnections of life evidence, advocacy, \& actions. Knowledge Quest, 43(3), 8.

VanderArk, T., \& Schneider, C. (2012). How digital learning contributes to deeper learning. Getting Smart. December. 
Vogt, C. (2005). Change: Motivational factors for women in engineering: Self-efficacy and academic self-confidence. Retrieved on February, 28, 2012.

Watson, D. (2001). Education And Information Technologies, 6(4), 251-266.

http://dx.doi.org/10.1023/a:1012976702296

\section{Biographical Notes}

Virgilio G. Medina Jr. has worked in Middle East countries as a school librarian for three years. With a Bachelor of Library and Information Science (cum laude) from the University of the Philippines, he is currently working at SEK International School in Doha Qatar. His professional and research interests center on the development of school libraries as digital libraries and how these can be effectively marketed to support the school's curriculum for a global society.

Dr Ross J. Todd is professor and chair of the Department of Library and Information Science at Rutgers, The State University of New Jersey, and Director of the Center for International Scholarship in School Libraries. His research focuses on how students learn in digital environments, and how school librarians can engage with evidence-based practices to ensure the on-going development of school libraries to meet the needs of students in 21 st schools.

Acknowledgement: The authors acknowledge the support given by Xiaofeng Li, doctoral student at the School of Communication \& Information, Rutgers University, for undertaking statistical analyses of the data. 